\title{
$\alpha$-Tocopherol modulates the low density lipoprotein receptor of human HepG2 cells
}

\author{
Sebely Pal*1, Andrew M Thomson ${ }^{2}$, Cynthia DK Bottema ${ }^{3}$ and \\ Paul D Roach 4
}

Address: ${ }^{1}$ Department of Nutrition, Dietetics and Food Sciences, Curtin University of Technology, Perth, Western Australia, ${ }^{2}$ Laboratory for Cancer Medicine and University Department of Medicine, University of Western Australia, Royal Perth Hospital, Perth, Western Australia, ${ }^{3}$ Department of Animal Science Waite Campus, University of Adelaide Glen Osmond, SA 5064, Australia and ${ }^{4}$ CSIRO Human Nutrition, PO Box 1004, SA 5000, Australia

Email: Sebely Pal* - s.pal@curtin.edu.au; Andrew M Thomson - athomson@cyllene.uwa.edu.au; Cynthia DK Bottema - s.pal@curtin.edu.au; Paul D Roach - drpauldr@hotmail.com

* Corresponding author

Published: 12 May 2003

Nutrition Journal 2003, 2:3
Received: 19 December 2002

Accepted: 12 May 2003

This article is available from: http://www.nutritionj.com/content/2/I/3

(C) $2003 \mathrm{Pal}$ et al; licensee BioMed Central Ltd. This is an Open Access article: verbatim copying and redistribution of this article are permitted in all media for any purpose, provided this notice is preserved along with the article's original URL.

\begin{abstract}
The aim of this study was to determine the effects of vitamin $E$ ( $\alpha$-tocopherol) on the low density lipoprotein (LDL) receptor, a cell surface protein which plays an important role in controlling blood cholesterol. Human HepG2 hepatoma cells were incubated for 24 hours with increasing amounts of $\alpha, \delta$, or $\gamma$-tocopherol. The LDL receptor binding activity, protein and mRNA, 3-hydroxy-3methylglutaryl coenzyme A (HMG-CoA) reductase mRNA, cell cholesterol and cell lathosterol were measured. The effect of $\alpha$-tocopherol was biphasic. Up to a concentration of $50 \mu \mathrm{M}, \alpha$ tocopherol progressively increased LDL receptor binding activity, protein and mRNA to maximum levels 2, 4 and 6-fold higher than control, respectively. The HMG-CoA reductase mRNA and the cell lathosterol concentration, indices of cholesterol synthesis, were also increased by $40 \%$ over control by treatment with $50 \mu \mathrm{M} \alpha$-tocopherol. The cell cholesterol concentration was decreased by $20 \%$ compared to control at $50 \mu \mathrm{M} \alpha$-tocopherol. However, at $\alpha$-tocopherol concentrations higher than $50 \mu \mathrm{M}$, the LDL receptor binding activity, protein and mRNA, the HMG-CoA reductase mRNA and the cell lathosterol and cholesterol concentrations all returned to control levels. The biphasic effect on the LDL receptor was specific for $\alpha$-tocopherol in that $\delta$ and $\gamma$-tocopherol suppressed LDL receptor binding activity, protein and mRNA at all concentrations tested despite the cells incorporating similar amounts of the three homologues. In conclusion, $\alpha$-tocopherol, exhibits a specific, concentration-dependent and biphasic "up then down" effect on the LDL receptor of HepG2 cells which appears to be at the level of gene transcription. Cholesterol synthesis appears to be similarly affected and the cell cholesterol concentration may mediate these effects.
\end{abstract}

\section{Introduction}

It has been known for over 60 years that the vitamin $\mathrm{E}$ ( $\alpha$ - tocopherol) status of rabbits can affect their plasma cholesterol concentration. In 1936, Morgulis and Spencer [1] 
reported that the plasma cholesterol was twofold higher than normal in rabbits made deficient in vitamin $\mathrm{E}$ and that dietary replenishment of the vitamin normalised the cholesterol concentration. This effect was later confirmed by others in the rat [2-4] as well as in the rabbit [5-7]. In animal models of diet-induced hypercholesterolaemia, where the animals are not deficient in vitamin $\mathrm{E}, \alpha$-tocopherol supplementation also often decreases plasma cholesterol [8-12]. This is not always the case however; in some studies either no change [13-15] or even an increase [16] in plasma cholesterol was observed. In the rat however, a concomitant deficiency in selenium may be more relevant to increases in plasma cholesterol than the induced deficiency in vitamin E [17]

Changes in the plasma cholesterol concentration may result from effects the vitamin has on liver cholesterol metabolism. Hepatic cholesterol synthesis has been found to be increased in vitamin E-deficient rabbits [5] and the conversion of cholesterol into bile acids was observed to be decreased $[5,6]$. Such an increase in cholesterolgenesis and a decrease in cholesterol catabolism is consistent with the increase in liver cholesterol concentration found in the vitamin E-deficient rat $[3,4]$.

There is however no data on the effects of $\alpha$-tocopherol, the biologically active homologue of vitamin E, [18] on the hepatic low density lipoprotein (LDL) receptor which is well known to play a major role in the control of plasma cholesterol $[19,20]$. The importance of the LDL receptor is most clearly seen in the human genetic disorder called familial hypercholesterolaemia where a deficiency in the receptor causes high levels of plasma cholesterol which lead to the premature development of atherosclerosis [20]. The LDL receptor is also highly regulated in that various dietary and pharmaceutical agents can affect its expression $[19,20]$

The aim of the present study was therefore to determine whether vitamin E could regulate the LDL receptor. Cultured human HepG2 hepatoma cells, highly differentiated hepatocytes known to express lipoprotein receptors, [21-23] were grown in the absence of added vitamin $E$. Three naturally occurring vitamin E homologues, $\alpha, \delta$ and $\gamma$-tocopherol [18] were tested for their effects on the HepG2 cell LDL receptor mRNA, protein and LDL-binding activity. The effect of $\alpha$-tocopherol on the mRNA of 3hydroxy-3-methylglutaryl coenzyme A (HMG-CoA) reductase, the rate-limiting enzyme in cholesterol biosynthesis, and on the cellular concentration of lathosterol, an index of cholesterol synthesis, was also determined. The cell's cholesterol concentration was also measured.

\section{Methods and materials Cell culture}

The HepG2 cells were grown under $5 \% \mathrm{CO}_{2}$ at $37^{\circ} \mathrm{C}$ in Dulbecco's Modified Eagles Medium (DMEM) supplemented with $12 \mu \mathrm{g} / \mathrm{ml}$ penicillin, $16 \mu \mathrm{g} / \mathrm{ml}$ gentamicin, $20 \mathrm{mM}$ HEPES buffer, $10 \mathrm{mM} \mathrm{NaOH}, 2 \mathrm{mM}$ L-glutamine and $10 \%(\mathrm{v} / \mathrm{v})$ fetal calf serum (FCS) (Commonwealth Serum Laboratories, Melbourne, Australia) as previously described [21-23]. For enrichment experiments, cells were grown to $80-90 \%$ confluency, and varying amounts of $\alpha$, $\delta$ or $\gamma$-tocopherol (Purity 95\%; Sigma-Aldrich, Castle Hill, Australia) in ethanol were added to supplemented DMEM and the cells were incubated in the media for $24 \mathrm{~h}$. The cells were then extensively washed in phosphate buffered saline (PBS: $10 \mathrm{mM}$ phosphate, $154 \mathrm{mM} \mathrm{NaCl}, \mathrm{pH} 7$ ) before being scraped from the flasks and resuspended in PBS. Cell viability was assessed using the trypan blue dye exclusion test. Cellular protein was determined using the method of Lowry et al [24].

\section{Cellular Tocopherol Content}

The tocopherol content of the cells was measured using the method of Yang and Lee [25]. Briefly, $1.0 \mathrm{ml}$ of $1 \%$ ascorbic acid in $100 \%$ ethanol added to $1.0 \mathrm{ml}$ of cell suspension (Alpha-tocopherol acetate was used as an internal standard) and heated at $70^{\circ} \mathrm{C}$ for $2 \mathrm{~min}$; then $0.3 \mathrm{ml}$ of saturated $\mathrm{KOH}$ was added and incubated for $30 \mathrm{~min}$ in a $70^{\circ} \mathrm{C}$ water bath. After cooling on ice, $1.0 \mathrm{ml}$ distilled water and $4.0 \mathrm{ml}$ hexane were added and shaken vigorously for $2 \mathrm{~min}$; then the phases were separated by centrifugation at room temperature, $3000 \times g$ for $10 \mathrm{~min}$. An aliquot of hexane phase $(3.0 \mathrm{ml})$ was pipetted and dried under a stream of $\mathrm{N} \mathrm{[2]} \mathrm{and} \mathrm{redisolved} \mathrm{in} 0.2 \mathrm{ml}$ methanol. The aliquots ( $20 \mathrm{ml}$ each) were injected to high performance liquid chromatography (Waters, Milford, MA, USA) for analysis on a C 18 column (5 mm $34.6 \mathrm{~mm} 3$ $25 \mathrm{~cm}$ ) with the mobile phase of methanol-water (95:5) and detected by a fluorometer set at excitation 205 and emission $340 \mathrm{~nm}$. The coefficient of variation over two assessments was less than $5 \%$.

\section{LDL receptor binding assay}

Human LDL, $1.025>d>1.050 \mathrm{~g} / \mathrm{ml}$, was isolated from 24 days-old blood (Red Cross, Adelaide, Australia) by sequential ultracentrifugation [26] and conjugated to colloidal gold (LDL-gold) as described. [27,28] Freshly collected and intact HepG2 cells (100 ug of protein) were incubated for $1 \mathrm{~h}$ at room temperature with LDL-gold (20 ug protein/ml) and buffer (60 mM Tris-HCL, pH 8.0, and $20 \mathrm{mg} / \mathrm{ml} \mathrm{BSA}$ ) in a total of $300 \mathrm{ul}$ either in the presence of $2 \mathrm{mM} \mathrm{Ca}\left(\mathrm{NO}_{3}\right)_{2}$ to measure total binding or $20 \mathrm{mM}$ EDTA to measure calcium-independent binding. Cells were then centrifuged at $400 \times g$ for $10 \mathrm{~min}$, resuspended and washed in $300 \mathrm{ul}$ of $2 \mathrm{mM} \mathrm{Ca}\left(\mathrm{NO}_{3}\right)_{2}$ for total binding or $300 \mathrm{ul}$ of $20 \mathrm{mM}$ EDTA ( $\mathrm{pH} 8.0)$ for nonspecific 
binding. After centrifugation at $400 \times \mathrm{g}$ for $10 \mathrm{~min}$, the cells were resuspended in $120 \mathrm{ul}$ of $4 \%(\mathrm{w} / \mathrm{v})$ gum arabic and the cell-bound LDL-gold was quantified using a silver enhancement solution (IntenSE BL kit, Amersham, Sydney, Australia) and a Cobas Bio autoanalyser (Roche Diagnostica, Nutley, NJ). The HepG2 cell LDL receptor binding activity was taken to be the total binding minus the calcium-independent binding and expressed as ng LDL protein bound per mg cell protein (ng LDL/mg cell). The binding of LDL-gold to the LDL receptor has been shown to be indistinguishable from the binding of native or ${ }^{125} \mathrm{I}$-LDL and the method has been found to be more sensitive than the ${ }^{125}$ I-LDL technique $[27,28]$. The coefficient of variation for measurement of LDL receptor binding activity is $10 \%$.

\section{LDL receptor protein mass assay}

The HepG2 cells were solubilized by incubation for $12 \mathrm{~h}$ in a solution of $1.5 \%(\mathrm{w} / \mathrm{v})$ Triton X-100 containing 50 $\mathrm{mM}$ Tris-maleate ( $\mathrm{pH} \mathrm{6}$ ), $2 \mathrm{mM} \mathrm{CaCl} \mathrm{Cl}_{2} 1 \mathrm{mM}$ phenylmethylsulphonyl fluoride (PMSF) and $10 \mathrm{mM}$ n-ethylmaleamide. Solubilized cell protein $(100 \mu \mathrm{g})$ and rainbow molecular weight-markers (Pharmacia LKB, Uppsala, Sweden) were separated by electrophoresis on $2-15 \%$ sodium dodecyl sulphate (SDS)-polyacrylamide gradient gels at $30 \mathrm{~mA}$ for $5 \mathrm{~h}$. Separated proteins were electrotransferred at $45 \mathrm{~V}$ for $12 \mathrm{~h}$ onto $0.45 \mu \mathrm{m}$ nitrocellulose membranes (Schleicher and Schuell, Dassel, Germany) and the membranes were blocked for one hour at room temperature in $10 \mathrm{mM}$ Tris-HCL buffer, $\mathrm{pH} 7.4$, containing $154 \mathrm{mM} \mathrm{NaCl}$ and $10 \%$ (w/v) skim milk powder.

After washing in $10 \mathrm{mM}$ Tris-HCL buffer, $\mathrm{pH}$ 7.4, containing $154 \mathrm{mM} \mathrm{NaCl}$ and $1 \%(\mathrm{w} / \mathrm{v})$ skim milk powder, the membranes were incubated with a polyclonal anti-LDL receptor antibody (3.7 $\mu \mathrm{g}$ protein/ml in $10 \mathrm{mM}$ Tris-HCL buffer, pH 7.4, containing $154 \mathrm{mM} \mathrm{NaCl}$ and $1 \%(\mathrm{w} / \mathrm{v})$ skim milk powder). The antibody was raised in rabbits against the LDL receptor purified from bovine adrenal cortex and recognises the LDL receptor of other species $[29,30]$. The membranes were then incubated with antirabbit IgG linked to horseradish peroxidase (Amersham, North Ryde, Australia), diluted 1:5000 in $10 \mathrm{mM}$ TrisHCL buffer, pH 7.4 containing $154 \mathrm{mM} \mathrm{NaCl}$ and $1 \%$ (w/ v) skim milk powder and subsequently washed twice with $10 \mathrm{mM}$ Tris-HCL buffer, pH 7.4, containing $154 \mathrm{mM} \mathrm{NaCl}$ and $2 \mathrm{mM} \mathrm{CaCl}_{2}$. The membranes were then soaked in enhanced chemiluminescence substrate solution for horseradish peroxidase (ECL detection kit, Amersham, North Ryde, Australia) and exposed to hyper-film ECL (Amersham, North Ryde, Australia) for 1 to $5 \mathrm{~min}$. The films were then scanned to determine the intensity of the LDL receptor protein bands using an LKB Ultrascan XL enhanced laser densitometer (Pharmacia LKB Biotechnolo- gy, North Ryde, Australia) and the measurements in arbitrary absorbance units were taken as the mass of LDL receptor protein in the HepG2 cells. The assay was optimised to give a linear response in the range of LDL receptor protein expressed by the HepG2 cells. The coefficient of variation for measurement of LDL receptor protein mass is $10 \%$.

\section{LDL receptor mRNA assay}

Cellular RNA was isolated from the HepG2 cells using the procedure of Chomcznski and Sacchi [31] and the LDL receptor mRNA was measured using reverse transcription and the polymerase chain reaction (PCR) as modified from the method of Powell and Kroon [32].

The RNA was reversed transcribed into cDNA along with a synthetic piece of cRNA, AW109 (Perkin-Elmer Cetus Instruments, Norwalk, CT) which was used as an internal standard because it contains primer site sequences unique to the $\mathrm{LDL}$ receptor. The reaction mixture $(11.94 \mu \mathrm{l})$ contained $1 \mu \mathrm{l}$ cell total RNA $(120 \mathrm{ng} / \mu \mathrm{l}), 1 \mu \mathrm{l}$ of AW109 cRNA $\left(4 \times 10^{4}\right.$ copies $\left./ \mu \mathrm{l}\right), 1 \mu \mathrm{l}$ PCR buffer $(100 \mathrm{mM}$ Tris $\mathrm{HCl}, \mathrm{pH} 8.3,500 \mathrm{mM} \mathrm{KCL}), 2 \mu \mathrm{l}$ of $25 \mathrm{mM} \mathrm{MgCl}_{2}, 0.5 \mu \mathrm{l}$ of RNasin $(20 \mathrm{U} / \mu \mathrm{l}$, Perkin-Elmer Cetus Instruments, Norwalk, CT), $0.5 \mu \mathrm{l}$ of random hexanucleotide primers $(50 \mu \mathrm{M}$, Perkin-Elmer Cetus Instruments, Norwalk, CT), $1.5 \mu \mathrm{l}$ each of $10 \mathrm{mM} \mathrm{dGTP}, 10 \mathrm{mM}$ dATP and $10 \mathrm{mM}$ dCTP, $0.94 \mu \mathrm{l}$ of $10 \mathrm{mM}$ dTTP (Perkin-Elmer Cetus Instruments, Norwalk, CT) and $0.5 \mu \mathrm{l}$ of Moloney Murine Leukemia Virus reverse transcriptase (C50 U/ $\mu$ l, PerkinElmer Cetus Instruments, Norwalk, CT). It was then heated to $23^{\circ} \mathrm{C}$ for $10 \mathrm{~min}, 45^{\circ} \mathrm{C}$ for $15 \mathrm{~min}, 95^{\circ} \mathrm{C}$ for $5 \mathrm{~min}$ in a thermal cycler (Perkin-Elmer Cetus Instruments, Norwalk, CT) and finally chilled on ice.

The LDL receptor CDNA was then amplified using the polymerase chain reaction (PCR) to incorporate in its primer-specific sequence a digoxigenin (DIG)-labelled dUT. The PCR mixture $(20 \mu \mathrm{l})$ contained $5 \mu \mathrm{l}$ of the reverse transcription reaction mixture, $0.5 \mu \mathrm{l}$ of $1 \mathrm{mM}$ digoxigenin-11-dUTP, $2 \mu \mathrm{l}$ of PCR buffer $(100 \mathrm{mM}$ Tris $\mathrm{HCl}$, $\mathrm{pH} 8.3,500 \mathrm{mM} \mathrm{KCL}), 0.25 \mu \mathrm{l}$ of AmpliTaq DNA Polymerase $(5 \mathrm{U} / \mu \mathrm{l}$, Perkin-Elmer Cetus Instruments, Norwalk, CT), $0.60 \mu \mathrm{l}$ of the LDL receptor downstream primer AW125 $(25 \mu \mathrm{M}$, Perkin Elmer Cetus, Norwalk, CT), $0.60 \mu \mathrm{l}$ of the LDL receptor upstream primer AW126 $(25 \mu \mathrm{M}$, Perkin Elmer Cetus, Norwalk, CT) and $11.05 \mu \mathrm{l}$ deionised $\mathrm{H}_{2} \mathrm{O}$. The mixture was overlaid with mineral oil and the amplification was done with a DNA thermal cycler (Perkin Elmer Cetus, Norwalk, CT) using the following conditions for 27 cycles: denaturation at $95^{\circ} \mathrm{C}$ for 1 min followed by primer annealing at $55^{\circ} \mathrm{C}$ for $1 \mathrm{~min}$ and then extension at $72^{\circ} \mathrm{C}$ for $1 \mathrm{~min}$. At the end of the $27 \mathrm{th}$ cycle, a final extension period of $10 \mathrm{~min}$ at $72^{\circ} \mathrm{C}$ was done. 
Each PCR reaction mixture $(10 \mu \mathrm{l})$ was size fractionated by electrophoresis for $90 \mathrm{~min}$ at $90 \mathrm{~V}$ in $3 \%(\mathrm{w} / \mathrm{v})$ agarose gels with $0.8 \mathrm{mM}$ Tris acetate, $\mathrm{pH}$ 8.5, and $0.04 \mathrm{mM}$ EDTA as running buffer. The DNA was then transferred onto positively charged nylon membranes (Boehringer Mannheim, Rose Park, Australia) by blotting for 4 hours in $0.15 \mathrm{M} \mathrm{Na}_{3}$ Citrate, $\mathrm{pH} 7.6$ and $1.5 \mathrm{M} \mathrm{NaCl}$. The nylon membranes were then baked for $1 \mathrm{~h}$ at $100^{\circ} \mathrm{C}$ and rinsed in $30 \mathrm{mM} \mathrm{Na}_{3}$ Citrate, $\mathrm{pH} 7.6$, and $0.3 \mathrm{M} \mathrm{NaCl}$. The membranes were subsequently incubated in $0.1 \mathrm{mM}$ Tris- $\mathrm{HCL}$, $\mathrm{pH} 7.5$, and $0.1 \mathrm{M} \mathrm{NaCl}$ for $5 \mathrm{~min}$ at room temperature and blocked for $30 \mathrm{~min}$ at room temperature in $0.1 \mathrm{mM}$ Tris-HCL, pH 7.5, 0.1 M NaCl and 10\% (w/v) skim milk powder. The membranes were then incubated for $30 \mathrm{~min}$ with an anti-digoxigenin-IgG antibody, conjugated to alkaline phosphatase (Boehringer Mannheim), diluted $1: 1000$ in $0.1 \mathrm{mM}$ Tris-HCL, $\mathrm{pH} 7.5,0.1 \mathrm{M} \mathrm{NaCl}$ and $1 \%$ $(\mathrm{w} / \mathrm{v})$ skim milk powder. The membranes were subsequently washed 3 times for $20 \mathrm{~min}$ in $0.1 \mathrm{mM}$ Tris-HCL, $\mathrm{pH} 7.5,0.1 \mathrm{M} \mathrm{NaCl}$, incubated in 0.1 M Tris-HCL, $\mathrm{pH}$ 9.5, $0.1 \mathrm{M} \mathrm{NaCl}$ and $50 \mathrm{mM} \mathrm{MgCl}_{2}$ for $5 \mathrm{~min}$ and then soaked for 5 min in ECL alkaline phosphatase substrate solution consisting of $100 \mu \mathrm{g} / \mathrm{ml} \mathrm{CSPD} \mathrm{(disodium} \mathrm{3-(4-methox-}$ yspiro \{1,2-dioxetane-3,2-(5-chloro) tricyclo [3.3.1.1]decan\}-4-y)phenyl phosphate) (Boehringer Mannheim, Rose Park, Australia) in 0.1 M Tris-HCL, pH 9.5, 0.1 M $\mathrm{NaCl}$ and $50 \mathrm{mM} \mathrm{MgCl}$. They were then blotted dried, sealed in plastic, incubated at $37^{\circ} \mathrm{C}$ for $20 \mathrm{~min}$ and finally exposed to hyper-film ECL (Amersham, North Ryde, Australia) for 5 to $30 \mathrm{~min}$. The films were scanned using the LKB Ultrascan XL enhanced laser densitometer (Pharmacia LKB Biotechnology, North Ryde, Australia) to determine the intensity of the two bands corresponding to 1) cellular LDL receptor mRNA at $258 \mathrm{bp}$ and 2) synthetic AW109 internal standard RNA at $301 \mathrm{bp}$. The amount of LDL receptor mRNA in the HepG2 cells was calculated relative to the intensity of the band for the known amount of AW109 RNA added as internal standard and was expressed per $\mu \mathrm{g}$ of cellular total RNA. The assay was optimised to give a linear response in the range of LDL receptor mRNA expressed by the HepG2 cells. The coefficient of variation for measurement of LDL receptor mRNA is less than $7 \%$.

\section{HMG-CoA reductase $m R N A$ assay}

The HMG-CoA reductase mRNA of HepG2 cells was measured using reverse transcription and the polymerase chain reaction, as described above for the LDL receptor mRNA [31,32]. The AW109 cRNA was also used as the internal standard in this assay because it contains coding sequences of the HMG-CoA reductase gene. The same PCR reaction mixture was used except that HMG-CoA reductase-specific primers were included, namely AW102 and AW104 (Perkin Elmer Cetus, Norfolk, CT) as downstream and upstream primers, respectively. The coefficient of var- iation for measurement of HMG-CoA reductase mRNA is $8 \%$.

\section{Cholesterol and lathosterol measurements}

Cells were frozen at $-80^{\circ} \mathrm{C}$ for at least $24 \mathrm{~h}$ and slowly thawed for sterol analysis. Thawed cells were centrifuged for $5 \mathrm{~min}$ at $400 \times \mathrm{g}$. They were then homogenised by resuspending in $1 \mathrm{ml}$ of SDS buffer (0.1\% SDS, $1 \mathrm{mM}$ EDTA and $0.1 \mathrm{M}$ Tris Base, $\mathrm{pH}$ 7.4) and taken up in a syringe with an 18 gauge needle 4-8 times. Cholesterol and lathosterol were then extracted using hexane, subjected to saponification, derivatised using Trisil-TBT (Power SilPrep Kit, Alltech, Deerfield, IL) and measured by gas chromatography (GC) as described by Wolthers et al [33]. The sterol concentrations were expressed relative to the cellular protein as measured using the method of Lowry et al [24]. Lathosterol is a precursor in the cholesterol biosynthetic pathway and has been used as an index of cholesterol synthesis [34]. The cholesterol in the media was measured in the same way. The coefficient of variation for measurement of cholesterol and lathosterol in our laboratory is $6 \%$.

\section{Results \\ Effects of $\alpha$-tocopherol on the LDL Receptor}

After incubation for $24 \mathrm{~h}$ in media containing 0 to $100 \mu \mathrm{M}$ $\alpha$-tocopherol, cultured HepG2 cells and their media were analysed for their vitamin E content. The amount of $\alpha$-tocopherol in the cells was found to increase linearly relative to the concentration added to the media at the start of the $24 \mathrm{~h}$ incubation (Fig. 1). The HepG2 cells therefore effectively incorporated $\alpha$-tocopherol at all concentrations. No $\alpha$-tocopherol was detected in cells or in the media of cells incubated in the absence of added $\alpha$-tocopherol.

The LDL receptor binding activity of the HepG2 cells incubated for $24 \mathrm{~h}$ in media containing 0 to $100 \mu \mathrm{M} \alpha$-tocopherol was measured as the calcium-dependent binding of colloidal gold-LDL. The effect of $\alpha$-tocopherol on this LDL receptor binding activity was found to be biphasic (Fig. 2A). In the first phase, the binding activity progressively increased to $120 \%$ of control with increasing concentrations of $\alpha$-tocopherol up to $50 \mu \mathrm{M}$ but, in a second phase, it progressively decreased from this level to control values with higher concentrations of the vitamin.

Since changes in LDL receptor binding activity usually reflect changes in the number of receptors [20], measured the relative amounts of LDL receptor protein present in the HepG2 cells incubated for $24 \mathrm{~h}$ in media containing 0 to $100 \mu \mathrm{M} \alpha$-tocopherol. Using a polyclonal antibody against the LDL receptor, a single band was visualized which corresponded to a protein with the molecular mass of the LDL receptor, $130 \mathrm{kDa}[20,27]$. The effect of $\alpha$-tocopherol on the LDL receptor protein was also found to be 


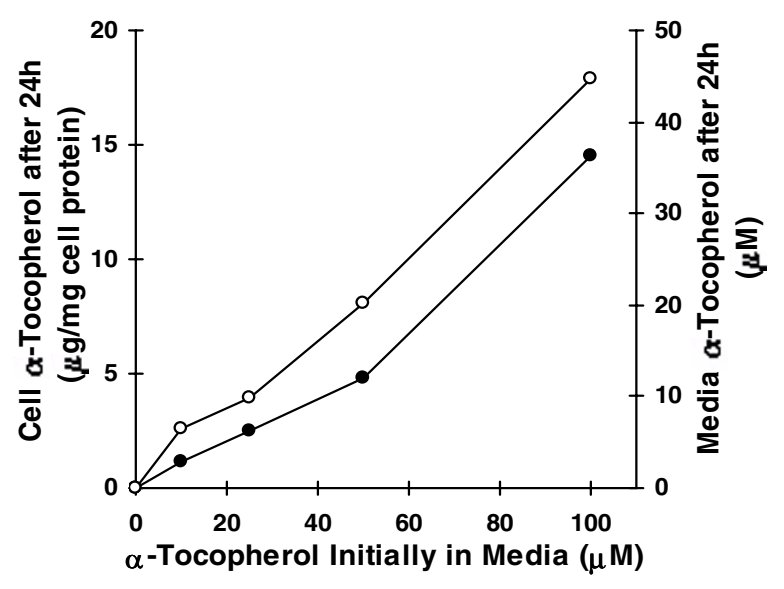

Figure I

The enrichment of HepG 2 cells with $\alpha$-tocopherol. Cells were incubated for $24 \mathrm{~h}$ at $37^{\circ} \mathrm{C}$ in media containing the indicated initial concentrations of $\alpha$-tocopherol. After $24 \mathrm{~h}$, the vitamin content of the cells ( $\boldsymbol{O}$, left $y$-axis scale) and the concentration of $\alpha$-tocopherol remaining in the media $(\bigcirc$, right $y$-axis scale) were measured by HPLC as described in Methods and materials. Values are means of duplicate determinations.

biphasic (Fig. 2B). The intensity of the LDL receptor band progressively increased up to 4.5 -fold above control with increasing concentrations of $\alpha$-tocopherol up to $50 \mu \mathrm{M}$ but then decreased from this level with higher concentrations of the vitamin. The biphasic changes observed in the binding of LDL-gold to the HepG2 cells can therefore be attributed to biphasic changes in the amount of LDL receptors present in the cells.

Since changes in both LDL receptor protein and binding activity usually reflect changes in gene transcription [20], we measured the relative amounts of LDL receptor mRNA present in the HepG2 cells incubated for $24 \mathrm{~h}$ in media containing 0 to $100 \mu \mathrm{M} \alpha$-tocopherol. The effect of $\alpha$-tocopherol on the LDL receptor mRNA was also found to be biphasic (Fig. 2C). The amount of receptor mRNA progressively increased up to 6.5-fold above control with increasing concentrations of $\alpha$-tocopherol up to $50 \mu \mathrm{M}$ but then decreased from this level at higher concentrations of the vitamin. The biphasic changes observed in the binding of LDL-gold to the HepG2 cells and the amount of LDL receptor protein present in the cells can therefore be attributed to biphasic changes in the amount of LDL receptor mRNA. Furthermore, this suggests a biphasic effect on gene transcription.
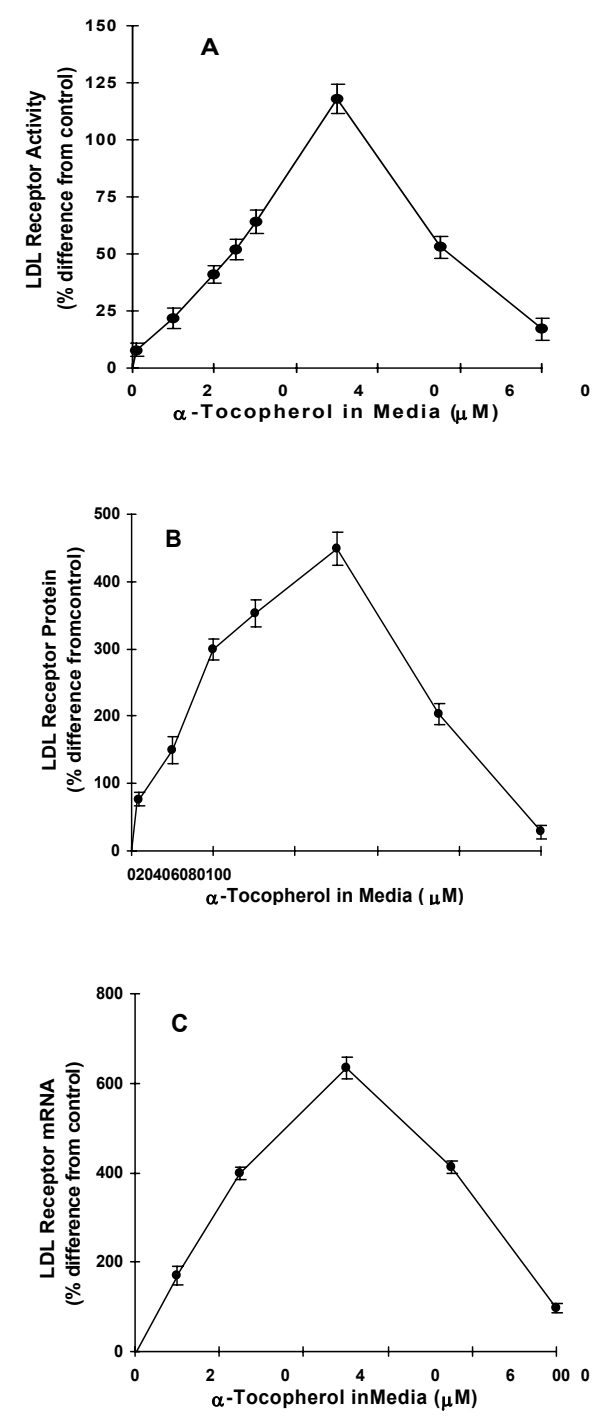

\section{Figure 2}

The effect of $\alpha$-tocopherol on LDL receptor binding activity, protein and mRNA of HepG2 cells. Cells were incubated for $24 \mathrm{~h}$ at $37^{\circ} \mathrm{C}$ in media containing the indicated concentrations of $\alpha$-tocopherol. The LDL receptor binding activity (A) was measured in triplicate using colloidal-gold LDL, the LDL receptor protein $(\mathbf{B})$ was measured by western blotting and the LDL receptor mRNA (C) was measured using a PCR and western blotting technique as described in Methods and materials and the data was expressed as the percent difference (mean \pm SEM of three experiments) from the values obtained with control cells not pretreated with $\alpha$-tocopherol. The LDL receptor activity of control cells averaged $30 \pm$ $4.4 \mathrm{ng} \mathrm{LDL} / \mathrm{mg}$ cell protein, the LDL receptor protein in control cells averaged $0.2 \pm 0.09$ absorbance units and the amount of LDL receptor mRNA in control cells averaged 4.0 $\pm 0.5 \times 10^{5}$ copies/ $\mu \mathrm{g}$ RNA. 


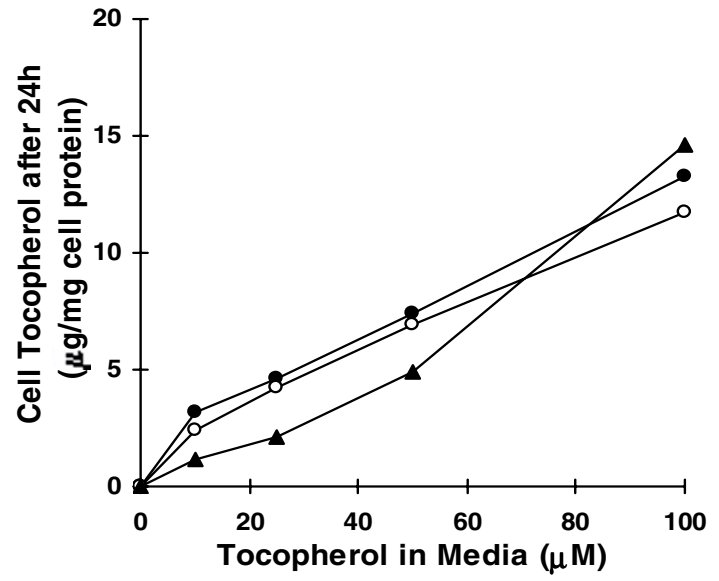

Figure 3

The enrichment of HepG2 cells with different tocopherols. Cells were incubated for $24 \mathrm{~h}$ at $37^{\circ} \mathrm{C}$ in media containing the indicated concentrations of either $\alpha$-tocopherol $(0), \delta$ tocopherol $(\bigcirc)$ or $\gamma$-tocopherol $(\mathbf{\Delta})$. After $24 \mathrm{~h}$, the tocopherols in the cells were measured by HPLC as described in Methods and materials. Values are means of duplicate determinations.

\section{Effects of $\delta$ - and $\gamma$-tocopherol on the LDL Receptor}

There are four naturally occurring tocopherols: $\alpha-, \beta-, \delta$ and $\gamma$-tocopherol [18]. To investigate whether the biphasic regulation of the LDL receptor observed with $\alpha$-tocopherol was a property of other tocopherols, HepG2 cells were incubated for $24 \mathrm{~h}$ in media containing either 0 to $100 \mu \mathrm{M} \alpha$-tocopherol, $\delta$-tocopherol or $\gamma$-tocopherol. All three tocopherols were similarly incorporated by the cells (Fig. 3) with the cellular content of each tocopherol increasing linearly relative to the concentration of the homologue present at the start of the $24 \mathrm{~h}$ incubation.

The LDL receptor binding activity (Fig. 4A), protein (Fig. $4 \mathrm{~B}$ ) and mRNA (Fig. 4C) were increased 2, 4.5 and 7-fold over control, respectively, at $50 \mu \mathrm{M} \alpha$-tocopherol but were reduced close to control levels at $100 \mu \mathrm{M} \alpha$-tocopherol. In contrast, LDL receptor binding activity (Fig. 4A), protein (Fig. 4B) and mRNA (Fig. 4C) were reduced compared to control at all concentrations of $\delta$ - and $\gamma$-tocopherol tested. Therefore, like the biphasic regulation seen with $\alpha$-tocopherol, the downregulation observed with $\delta$ - and $\gamma$ tocopherol appeared to be at the level of gene transcription.

The tocopherols, at all concentrations, had no effect on the growth of the HepG2 cells as judged by total cellular
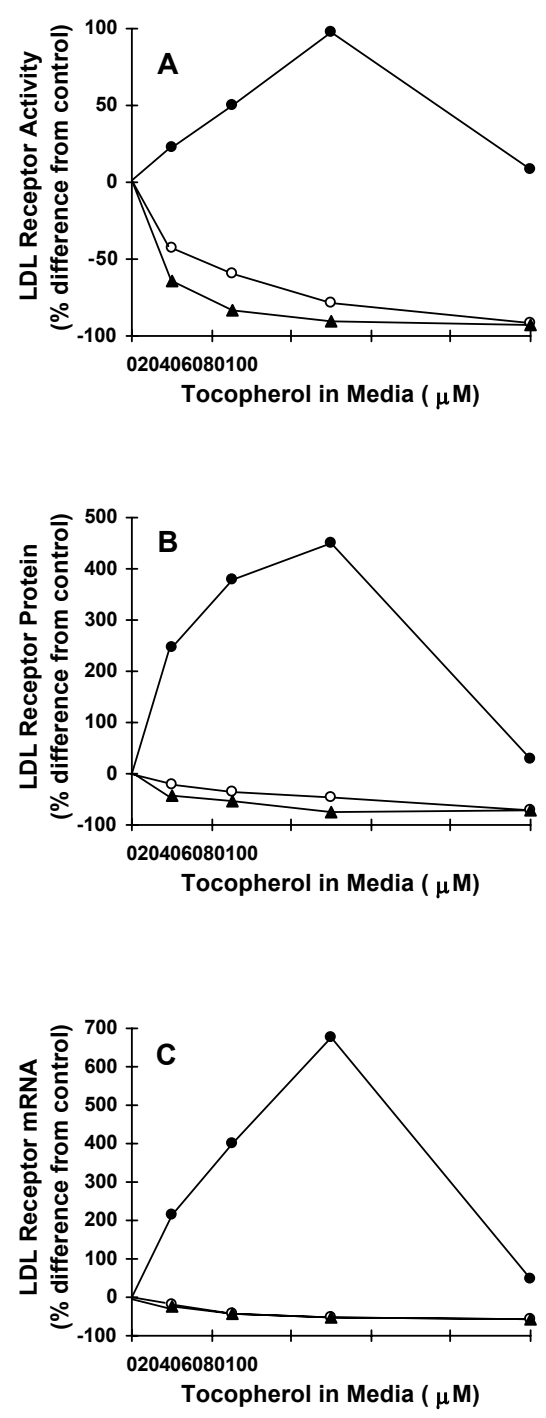

\section{Figure 4}

The effects of different tocopherols on the LDL receptor binding activity, protein and mRNA of HepG2 cells. Cells were incubated for $24 \mathrm{~h}$ at $37^{\circ} \mathrm{C}$ in media containing the indicated concentrations of either $\alpha$-tocopherol $(\bullet), \delta$-tocopherol $(\bigcirc)$ or $\gamma$-tocopherol $(\mathbf{\Delta})$. The LDL receptor binding activity (A) was measured in triplicate using colloidal-gold LDL. The LDL receptor protein (B) was measured by western blotting and the LDL receptor mRNA (C) was measured using a PCR and western blotting technique as described in Methods and materials and the data was expressed as the percent difference from the values obtained with control cells not pretreated with $\alpha$-tocopherol. The LDL receptor activity in control cells averaged $40 \pm 5 \mathrm{ng} \mathrm{LDL} / \mathrm{mg}$ cell protein, the LDL receptor protein in control cells averaged 0.85 \pm 0.39 absorbance units and the amount of LDL receptor mRNA in control cells averaged $4.0 \pm 0.5 \times 10^{-5}$ copies $/ \mu \mathrm{g}$ RNA. 


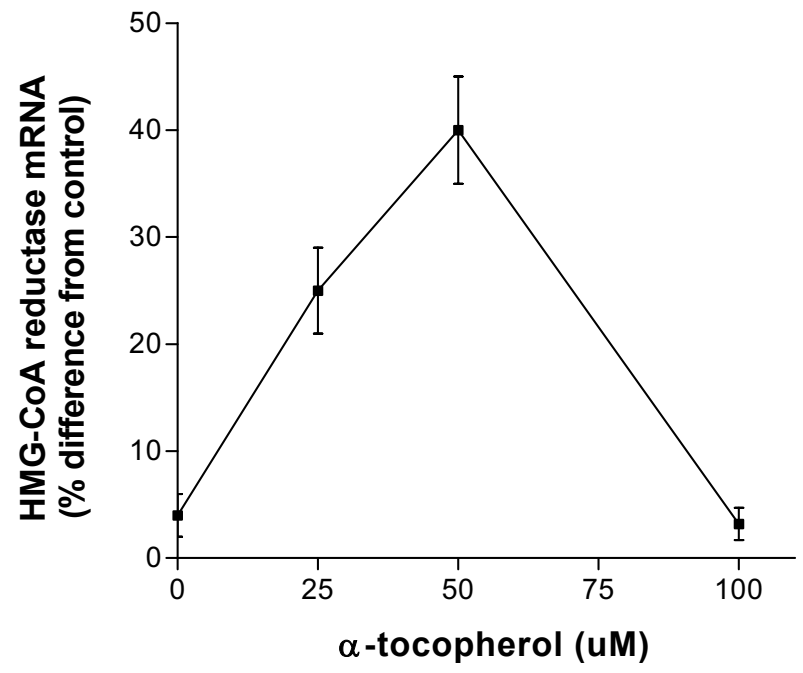

\section{Figure 5}

The effects of different tocopherols on HMG-CoA mRNA mRNA of HepG 2 cells. Cells were incubated for $24 \mathrm{~h}$ at $37^{\circ} \mathrm{C}$ in media containing the indicated concentrations of $\alpha$ tocopherol. HMG-CoA mRNA was measured using a PCR and western blotting technique as described in Methods and materials and the data was expressed as the percent difference from the values obtained with control cells not pretreated with $\alpha$-tocopherol. The HMG-CoA mRNA in control cells averaged $4.2 \pm 0.8 \times 10^{5}$ copies/ $\mu$ g RNA.

protein nor on cell viability as judged by the trypan blue dye exclusion test.

\section{Effects of $\alpha$-tocopherol on the HMG-CoA reductase mRNA and on cell sterols}

The HMG-CoA reductase reaction is the rate limiting step in the de novo biosynthesis of cholesterol and regulation of the enzyme is often in parallel to that of the LDL receptor [20]. Vitamin E had the same biphasic effect on the HMG-CoA reductase mRNA as it did on LDL receptor binding activity, protein and mRNA. At $25 \mu \mathrm{M} \alpha$-tocopherol, the HMG CoA reductase mRNA was increased by $25 \pm$ $2.5 \%$ over control, at $50 \mu \mathrm{M}$ it was increased by $40 \pm 3.5 \%$ but at $100 \mu \mathrm{M}$ it was close to control levels, only $3.2 \pm$ $2.0 \%$ higher. The amount of HMG-CoA reductase mRNA in control cells averaged $4.2 \pm 0.8 \times 10^{5}$ copies $/ \mu \mathrm{g}$ RNA(Figure 5).

Consistent with the effects of vitamin E on the HMG-CoA mRNA, the concentration of lathosterol in the cells, an indicator of cholesterol synthesis, was also increased by $40 \%$ over control at $50 \mu \mathrm{M} \alpha$-tocopherol but it was close to control levels at 75 an $100 \mu \mathrm{M} \alpha$-tocopherol (Fig. 6).

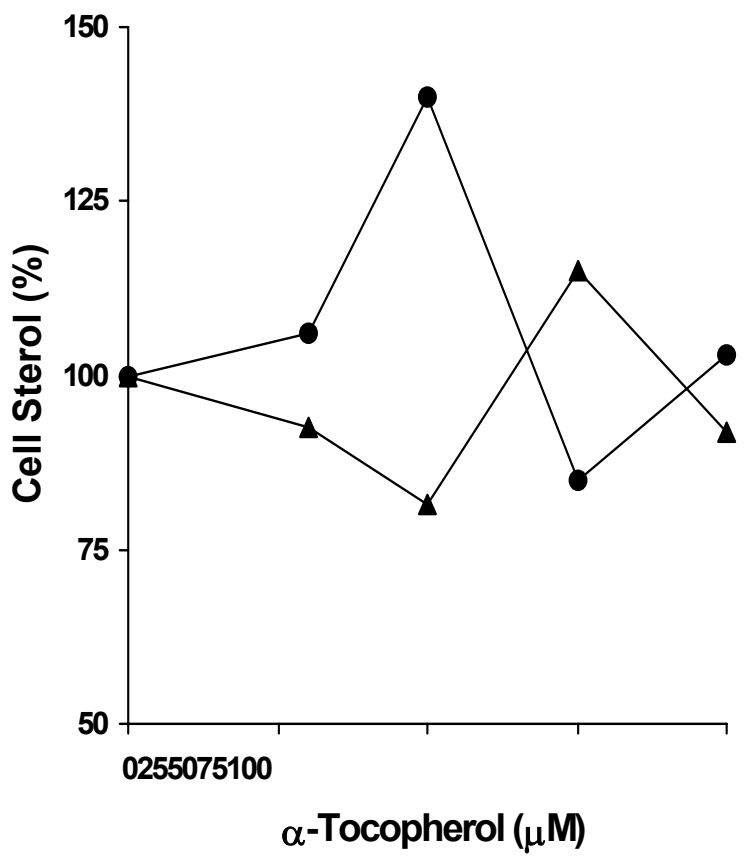

\section{Figure 6}

The effect of $\alpha$-tocopherol on the cellular concentration of cholesterol and lathosterol of HepG2 cells. Cells were incubated for $24 \mathrm{~h}$ at $37^{\circ} \mathrm{C}$ in media containing the indicated concentrations of $\alpha$-tocopherol. Cellular cholesterol $(\mathbf{)})$ and lathosterol $(\mathbf{A})$ were measured in duplicates by $\mathrm{GC}$ as described in Methods and materials and the data was expressed relative to the values of control cells not pretreated with $\alpha$-tocopherol set at $100 \%$. The cholesterol concentration in control cells was $9 \mathrm{mg} / \mathrm{mg}$ cell protein and the lathosterol concentration was $13 \mu \mathrm{g} / \mathrm{mg}$ cell protein.

In contrast, the effects of vitamin $\mathrm{E}$ on the concentration of cholesterol in the cells was inversely related to its effects on cellular lathosterol (Fig. 6). At $50 \mu \mathrm{M} \alpha$-tocopherol, the cell cholesterol concentration was reduced by $20 \%$ compared to control but it was close to control values at 75 and $100 \mu \mathrm{M} \alpha$-tocopherol. Vitamin E however had little effect on the cholesterol concentration in the media; the values were $92 \%, 92 \%, 105 \%$ and $94 \%$ of control at $30,50,75$ and $100 \mu \mathrm{M} \alpha$-tocopherol, respectively. The cholesterol concentration in the media of the control cells was $25 \mu \mathrm{M}$.

\section{Discussion}

$\alpha$-Tocopherol consistently modulated the expression of the LDL receptor of HepG2 cells in a biphasic manner. The receptor was progressively upregulated when the cells were incubated with concentrations up to $50 \mu \mathrm{M} \alpha$-tocopherol but it was downregulated towards control levels at higher concentrations. The biphasic effect was observed 
whether LDL receptor binding activity, protein or mRNA was measured. The upregulation phase was specific for $\alpha$ tocopherol in that only downregulation of the LDL receptor was observed with $\delta$ - and $\gamma$-tocopherol at comparable concentrations. The $\alpha$-tocopherol also had the same biphasic effect on the mRNA of HMG-CoA reductase, the rate-limiting enzyme in cholesterol biosynthesis [20] and on the cellular lathosterol concentration, another index of cholesterol synthesis. $[33,34]$ The cell cholesterol concentration may have mediated the biphasic "up-then-down" effects on the LDL receptor and on cholesterol synthesis because $\delta$-tocopherol had an inverse "down-then up" effect on the cell cholesterol concentration.

The parallel biphasic modulation by $\alpha$-tocopherol of LDL receptor binding activity, protein and mRNA suggests that the effect was at the level of gene transcription. For the same reason, the downregulation observed with $\delta$ - and $\gamma$ tocopherol also appeared to be at the level of gene transcription. This is consistent with what is known about the regulation of the LDL receptor [20], it is well documented to be at the level of gene transcription whether it is dependent [35] or independent [36] of sterols. The concomitant "up-then-down" biphasic change in the HMGCoA reductase mRNA observed with $\alpha$-tocopherol also suggests that the transcription of both the LDL receptor and the HMG-CoA reductase genes was coordinately upregulated. This parallel regulation fits very well with the "down-then-up' effects of vitamin E on the cellular cholesterol concentration as both genes are known to respond to the same sterol feedback regulatory system [35,37]. Furthermore, the same "up-then-down" effect on the cellular lathosterol concentration indicates that the changes in HMG-CoA reductase mRNA were translated into parallel changes in cholesterol synthesis.

The upregulation of the LDL receptor by concentrations of $\alpha$-tocopherol up to $50 \mu \mathrm{M}$ is consistent with a report on the effect of $\gamma$-tocotrienol, a natural farnesylated analogue of the tocopherols [18] on the LDL receptor. In that study, $10 \mu \mathrm{M} \gamma$-tocotrienol, the only concentration tested, increased the amount of LDL receptor protein in HepG2 cells by $75 \%$ over control [38]. The tocotrienol also slightly decreased the HMG-CoA reductase mRNA and inhibited cholesterol synthesis by further inhibiting HMG CoA reductase activity at a post-transcriptional level [38]. In contrast, in the present study, there was an increase in cellular lathosterol concentration, an index of cholesterol synthesis [33,34]. The results herein are also not consistent with the evidence that vitamin $\mathrm{E}$ decreases cholesterol synthesis in vitamin E-deficient rabbits [5].

The "up then down" regulation seen with $\alpha$-tocopherol is a novel observation for the LDL receptor and cholesterol synthesis. However, the vitamin $\mathrm{E}$ homologue has previously been found to have concentration-dependent biphasic "up then down" effects on phospholipase $\mathrm{A}_{2}$ activity [39] and on the synthesis of prostagladins [40] and prostacyclins [41]. There have also been reports that prostaglandins can upregulate the LDL receptor, an effect that appears to be mediated through camp [42,43]. However, in contrast to the present findings, the effects on prostaglandin synthesis were not specific to $\alpha$-tocopherol in that the $\beta, \delta$ and $\gamma$ tocopherols also had biphasic "up then down" effects [40]. Vitamin E is also known to have effects on other cellular regulatory systems including the protein kinase C (PKC) signalling pathway [44] which is also involved in the regulation of the LDL receptor $[36,45]$. Clearly, there are a number of regulatory pathways through which $\alpha$-tocopherol could have effects on the LDL receptor. The present observations are therefore generally consistent with what is already known about the effects of vitamin $\mathrm{E}$ on cellular metabolism.

The observed upregulation of the LDL receptor at concentrations from 0 to $50 \mu \mathrm{M} \alpha$-tocopherol offers an explanation for the high plasma cholesterol seen in vitamin Edeficient animals and its lowering by replenishment with the vitamin [1-7]. Tocopherols were undetectable when the HepG2 cells were grown in the absence of added tocopherols; these cells therefore essentially mimic liver cells in vitamin E-deficient animals. If replenishment with $\alpha$ tocopherol in deficient animals upregulates the hepatic LDL receptor as it does in the vitamin E-free HepG2 cells, then the clearance of LDL and other lipoproteins from the circulation should increase $[19,20]$ and contribute to the lowering of the high plasma cholesterol seen in vitamin Edeficient animals.

The biphasic "up then down" nature of the LDL receptor response to the increasing $\alpha$-tocopherol concentrations in the present study may also explain the variable effects that dietary supplementation with vitamin E can have on plasma cholesterol when animals are not deficient in the vitamin. In such animals made hypercholesterolaemic by diet, $\alpha$-tocopherol supplementation can result in 1) a decrease $[8,12], 2)$ an increase [16] or 3) no change [13-15] in plasma cholesterol. The present results would suggest that the vitamin E level prior to supplementation could have been 1) lower than optimal, 2) optimal or 3) higher than optimal for maximal LDL receptor activity, respectively and thus result in 1) an increase, 2) a decrease or 3) no change in LDL receptor activity, respectively, upon supplementation.

In humans, vitamin E deficiency is very rare and plasma levels of the vitamin are generally higher than in animals. Nonetheless, in a recent placebo controlled, cross-over human trial, doses of vitamin E $(73.5 \mathrm{mg} /$ day for 6 weeks) was observed to significantly decrease plasma cho- 
lesterol by $5.3 \%$ and plasma triglycerides by $18.3 \%$ while increasing the plasma $\alpha$-tocopherol from 26.8 to $32.2 \mu \mathrm{M}$ $[46]$, concentrations within the range where the increase in the LDL receptor was observed in the present study. In the same study, $500 \mathrm{mg} /$ day of vitamin $\mathrm{C}$ also decreased plasma cholesterol by $6.2 \%$ and triglycerides by $8.5 \%$.

However, other recent human intervention studies with generally higher vitamin $\mathrm{E}$ doses have mostly shown no change or an increase in plasma cholesterol [47-50]. Importantly, the increase in plasma cholesterol, when seen, is due mainly to an increase in high density lipoprotein (HDL) cholesterol, a lipoprotein which is considered to be anti-atherogenic [50]. Why HDL cholesterol is increased rather than LDL cholesterol, as might be expected if the LDL receptor is decreased, is unclear. However, the LDL receptor is only one of the factors which can affect plasma cholesterol, and $\alpha$-tocopherol may have effects on other aspects of cholesterol and lipoprotein metabolism.

In conclusion, $\alpha$-tocopherol has been shown to have a concentration-dependent biphasic "up then down" effect on the LDL receptor of HepG2 cells. The effect appears to be at the level of gene transcription and is specific for $\alpha$ tocopherol in that $\delta$ - and $\gamma$-tocopherol only had downregulatory effects. The $\alpha$-tocopherol also had the same effects on HMG-CoA reductase mRNA levels and the cellular lathosterol concentration, indices of cholesterol synthesis. These vitamin E effects may have been mediated through the observed "down-then-up" effect on the cellular cholesterol concentration. These results may explain the hypercholesterolaemia observed in animal models of vitamin E deficiency and may be relevant to the variable effect $\alpha$-tocopherol supplementation has on plasma cholesterol in animals and humans not deficient in the vitamin.

\section{Acknowledgments}

We would like to thank Dr. Paul Kroon and Dr. Elizabeth Powell, (Dept. of Biochemistry, University of Queensland), for teaching us the measurement of mRNA by quantitative PCR with a nonradioactive label. Special thanks are due to Calliope Triantafilidis (CSIRO) for all her expert technical assistance and thanks to Dr. Mavis Abbey (CSIRO), Dr. Paul Nestel (CSIRO) and Dr. Andrew Thomson (Adelaide Uni.) for their support and advice.

\section{References}

I. Morgulis $\mathrm{S}$ and Spencer HC Studies on the blood and tissues in nutritional muscular dystrophy J Nutr 1936, I 2:173-190

2. Chen LH, Liao $S$ and Packett LV Interaction of dietary vitamin E and protein level or lipid source with serum cholesterol level in rats J Nutr 1972, 102:729-732

3. Kaseki H, Kim EY, Whisler RL and Cornwell DG Effect of an oral dose of vitamin $E$ on the vitamin $E$ and cholesterol content of tissues of the vitamin E-deficient rat J Nutr 1986, I I6:16311639

4. Yasuda M, Fujita $T$ and Mizunoya $Y$ Liver and plasma lipids in vitamin E-deficient rats Chem Pharm Bull 1979, 27:447-45 I

5. Eskelson CD, Jacobi HP and Fitch DM Some effects of vitamin E deficiency on in vitro cholesterol metabolism Physiol Chem Phys 1973, 5:319-329
6. Chupukcharoen $\mathrm{N}$, Komaratat $P$ and Wilairat $P$ Effects of vitamin E deficiency on the distribution of cholesterol in plasma lipoproteins and the activity of cholesterol $7 \alpha$-hydroxylase in rabbit liver J Nutr 1985, I I 5:468-472

7. Oriani G, Salvatori G, Maiorano G, Belisario MA, Pastinese A, Manchisi $A$ and Pizzuti $G$ Vitamin $E$ nutritional status and serum lipid pattern in normal weanling rabbits J Animal Sci 1997, 75:402-408

8. Wilson RB, Middleton CC and Sun GY Vitamin E, antioxidants and lipid peroxidation in experimental atherosclerosis of rabbits J Nutr 1978, 108: 1858-1867

9. Westrope KL, Miller RA and Wilson RB Vitamin E in a rabbit model of endogenous hypercholesterolemia and atherosclerosis Nutr Reports Internat 1982, 25:83-88

10. Phonpanichrasamee $\mathrm{C}$, Komaratat $\mathrm{P}$ and Wilairat $\mathrm{P}$ Hypocholesterolemic effect of vitamin $E$ on cholesterol-fed rabbit Internat J Vit Nutr Res 1990, 60:240-244

II. Wójcicki J, Rózewicka L, Barcew-Wiszniewska B, Samochowiec L, Juzwiak S, Kadlubowska D, Tustanowski $S$ and Juzyszyn $Z$ Effect of selenium and vitamin $E$ on the development of experimental atherosclerosis in rabbits Atherosclerosis 1991, 87:9-16

12. Ozer NK, Sirikci O, Taha S, San T, Moser U and Azzi A Effect of vitamin $E$ and probucol on dietary cholesterol-induced atherosclerosis in rabbits Free Rad Biol Med 1998, 24:226-233

13. Morel DW, de la Llera-Moya M and Friday KE Treatment of cholesterol-fed rabbits with dietary vitamins $E$ and $C$ inhibits lipoprotein oxidation but not development of atherosclerosis J Nutr 1994, I 24:2123-2। 30

14. Parker RA, Sabrah T, Cap M and Gill BT Relation of vascular oxidative stress, $\alpha$-tocopherol, and hypercholesterolemia to early atherosclerosis in hamsters Arterioscler Thromb Vasc Biol 1995, 15:349-358

15. Sulli KC, Sun J, Giraud DW, Moxley RA and Driskell JA Effects of $\beta$ carotene and $\alpha$-tocopherol on the levels of tissue cholesterol and triglyceride in hypercholesterolemic rabbits $J$ Nutr Biochem 1998, 9:344-350

16. Prasad $K$ and Kalra J Oxygen free radicals and hypercholesterolemic atherosclerosis:effect of vitamin E Am Heart J 1993, I 25:958-973

17. Stone $W L$ The effects of cholesterol supplementation on plasma lipoprotein-cholesterol levels in rats fed diets deficient in vitamin E and/or selenium Nutr Res 1988, 8: I06 I-107|

18. Burton GW Vitamin E: molecular and biological function Proc Nutr Soc 1994, 53:25I-262

19. Dietschy JM, Turley SD and Spady DK Role of liver in the maintenance of cholesterol and low density lipoprotein homeostasis in different animal species, including humans J Lipid Res 1993, 34:1637-1659

20. Brown MS and Goldstein JL A receptor-mediated pathway for cholesterol homeostasis Science 1986, 232:34-47

21. Havekes LM, De Wit ECM and Princen HMG Cellular free cholesterol in Hep G2 cells is only partially available for down-regulation of low-density-lipoprotein receptor activity Biochem J 1987, 247:739-746

22. Kambouris AM, Roach PD and Nestel PJ Demonstration of a high density lipoprotein (HDL)-binding protein in Hep G2 cells using colloidal gold-HDL conjugates FEBS Lett 1988, 230:176180

23. Kambouris AM, Roach PD, Calvert GD and Nestel PJ Retroendocytosis of high density lipoproteins by the human hepatoma cell line, HepG2 Arteriosclerosis 1990, I 0:582-590

24. Lowry OH, Rosebrough NJ, Farr AL and Randall RJ Protein measurement with the Folin phenol reagent J Biol Chem 195I, 193:265-275

25. Yang CS and Lee M-J Methodology of plasma retinol, tocopherol and carotenoid assays in cancer prevention studies J Nutr Growth Cancer 1987, 4:19-27

26. Havel RJ, Eder HA and Bragdon $\mathrm{JH}$ The distribution and chemical composition of ultracentrifugally separated lipoproteins in human serum J Clin Invest 1955, 34: I 345-1353

27. Roach PD, Zollinger $M$ and Noël S-P Detection of the low density lipoprotein (LDL) receptor on nitrocellulose paper with colloidal gold-LDL conjugates J Lipid Res I987, 28: 15I5-I52 I

28. Roach PD, Hosking J, Clifton PM, Bais R, Kusenic B, Coyle P, Wight MB, Thomas DW and Nestel PJ The effects of hypercholesterolemia, simvastatin and dietary fat on the low density 
lipoprotein receptor of unstimulated mononuclear cells Atherosclerosis 1993, 103:245-254

29. Roach PD, Balasubramaniam S, Hirata F, Abbey M, Szanto A, Simons LA and Nestel PJ The low-density lipoprotein receptor and cholesterol synthesis are affected differently by dietary cholesterol in the rat Biochim Biophys Acta 1993, 1 170:165-172

30. Balasubramaniam S, Szanto $A$ and Roach PD Circadian rhythm in hepatic low-density-lipoprotein (LDL)-receptor expression and plasma LDL levels Biochem J 1994, 298:39-43

31. Chomczynski P and Sacchi N Single-step method of RNA isolation by acid guanidinium thiocyanate-phenol-chlorophorm extraction Anal Biochem 1987, 162:156-159

32. Powell EE and Kroon PA Measurement of mRNA by quantitative PCR with a nonradioactive label J Lipid Res 1992, 33:609614

33. Wolthers BG, Walrecht HT, vander Molen JC, Nagel GT, Van Doormaal JJ and Wijnandts PN Use of determinants of 7-lathosterol ( $5 \alpha$-cholest-7-en-3 $\beta$-ol) and other cholesterol precursors in serum in the study and treatment of disturbances of sterol metabolism, particularly cerebrotendinous xanthomatosis J Lipid Res 1991, 32:603-612

34. Kempen HJM, Glatz JFC, Gevers Leuven JA, van der Voort HA and Katan MB Serum lathosterol concentration is an indicator of whole-body cholesterol synthesis in humans J Lipid Res 1988, 29:1149-1155

35. Wang X, Sato R, Brown MS, Hua X and Goldstein JL SREBP-I, a membrane-bound transcription factor released by sterolregulated proteolysis Cell 1994, 77:53-62

36. Makar RSJ, Lipsky PE and Cuthbert JA Sterol-independent, sterol response element-dependent, regulation of low density lipoprotein receptor gene expression / Lipid Res 1998, 39: I647- 6554

37. Millinder Vallett S, Sanchez HB, Rosenfeld JM and Osborne TF A direct role for sterol regulatory element binding protein in activation of 3-hydroxy-3-methylglutaryl coenzyme A reductase gene J Biol Chem 1996, 27 I: I 2247-12253

38. Parker RA, Pearce BC, Clark RW, Gordon DA and Wright JJK Tocotrienols regulate cholesterol production in mammalian cells by post-transcriptional suppression of 3-hydroxy3methylglutaryl-coenzyme A reductase J Biol Chem 1993, 268: I I230-II 238

39. Tran K, Wong JT, Lee E, Chan AC and Choy PC Vitamin E potentiates arachidonate release and phospholipase $A_{2}$ activity in rat heart myoblastic cells Biochem J 1996, 3 1 9:385-39 I

40. Diplock AT, Xu G-L, Yeow C-L and Okikiola M Relationship of tocopherol structure to biological activity, tissue uptake, and prostaglandin biosynthesis Ann NY Acad Sci 1989, 570:72-84

41. Weimann BJ, Steffen $H$ and Weiser H Effects of $\alpha-$ and $\gamma$-tocopherol $(\alpha-T, \gamma-T)$ and $\alpha$-tocotrienol $(\alpha-T T)$ on the spontaneous and induced prostacyclin $\left(\mathrm{PGI}_{2}\right)$ synthesis from cultured human endothelial cells (HEC) and rat aorta segments ex vivo Ann NY Acad Sci 1989, 570:530-532

42. Nield $\mathrm{H}$ and Middleton $\mathrm{B}$ Transient elevation of CAMP by prostaglandins triggers subsequent up-regulation of LDL receptor activity in cultured human cells Biochem Soc Trans 1994, 22:210S

43. Nield $\mathrm{H}$ and Middleton $\mathrm{B}$ Prostaglandins which elevate cyclic AMP increase low density lipoprotein receptor mRNA and activity in human extra-hepatic cells Biochem Soc Trans 1995, 23:5S

44. Azzi A, Boscoboinik D, Marilley D, Özer NK, Stäuble B and Tasinato $A$ Vitamin $E$ : a sensor and an information transducer of the cell oxidation state Am J Clin Nutr 1995, 62: I337S- I346S

45. Kumar A, Chambers TC, Cloud-Helfin BA and Mehta KD Phorbol ester-induced low density lipoprotein receptor gene expression in HepG 2 cells involves protein kinase C-mediated p42/ 44 MAP kinase activation J Lipid Res 1997, 38:2240-2248

46. Hamilton IM], Gilmore WS, Benzie IFF, Mulholland CW and Strain I] Interactions between vitamins $C$ and $E$ in human subjects Brit J Nutr 2000, 84:26I-267

47. Stephens NG, Parsons A, Schofield PM, Kelly F, Cheeseman K, Mitchinson MJ and Brown MJ Randomised controlled trial of vitamin $E$ in patients with coronary disease: Cambridge Heart Antioxidant Study (CHAOS) Lancet 1996, 347:78I-786

48. Princen HMG, van Duyvenvoorde W, Buytenhek R, van der Laarse A, van Poppel G, Gervers Leuven JA and van Hinsberg VWM Supplementation with low doses of vitamin E protects LDL from lipid peroxidation in men and women Arterioscler Tromb Vasc Biol 1995, 15:325-333

49. Jialial I, Fuller CJ and Huet BA The effect of $\alpha$-tocopherol supplementation on LDL oxidation: A dose-response study Arterioscler Thromb Vasc Biol 1995, I 5:190-198

50. Muckle TJ and Nazir DJ Variation in human blood high density lipoprotein response to oral vitamin $\mathbf{E}$ megadosage $\mathrm{Am} J \mathrm{Clin}$ Pathol 1989, 91:165-171
Publish with Bio Med Central and every scientist can read your work free of charge

"BioMed Central will be the most significant development for disseminating the results of biomedical research in our lifetime. "

Sir Paul Nurse, Cancer Research UK

Your research papers will be:

- available free of charge to the entire biomedical community

- peer reviewed and published immediately upon acceptance

- cited in PubMed and archived on PubMed Central

- yours - you keep the copyright

Submit your manuscript here:

http://www.biomedcentral.com/info/publishing_adv.asp 